\title{
COLD ROLLING OF ALUMINUM FOUNDRY ALLOY
}

\author{
DOLZHANSKYI A.M. ${ }^{1}$, Dr. Sc. (Tech.), Prof., \\ KUTSOVA V.Z ${ }^{2}$, Dr. Sc. (Tech.), Prof., \\ AYUPOVA T.A..$^{*}$, Cand. Sc. (Tech.)., Assoc. Prof., \\ STOROZHKO K.D. ${ }^{4}$, Student, \\ RYBKIN O.P. ${ }^{5}$, Student
}

\begin{abstract}
${ }^{1}$ Department of Quality, Standardization and Certification, National Metallurgical Academy of Ukraine, 4, Haharina ave., 49600, Dnipro, Ukraine, tel. +38 (056) 746-05-49, e-mail tk136@ua.fm, ORCID ID:0000-0002-7552-3012

${ }^{2}$ Department of Material Science named after Yu.M.Taran-Zhovnir, National Metallurgical Academy of Ukraine, 4, Haharina ave., 49600, Dnipro, Ukraine, tel. +38 (056) 374-89-36, e-mail kaf.material@metal.nmetau.edu.ua, ORCID ID: 0000-0003-2413-679X

$3^{*}$ Department of Material Science named after Yu.M.Taran-Zhovnir, National Metallurgical Academy of Ukraine, 4, Haharina ave., 49600, Dnipro, Ukraine, tel. +38 (056) 374-89-36, e-mail kaf.material@metal.nmetau.edu.ua, ORCID ID 0000-0002-5706-4211

${ }^{4}$ Department of Material Science named after Yu.M.Taran-Zhovnir, National Metallurgical Academy of Ukraine, 4, Haharina ave., 49600, Dnipro, Ukraine, tel. +38 (056) 374-89-36, e-mail kaf.material@metal.nmetau.edu.ua

${ }^{5}$ Department of Material Science named after Yu.M.Taran-Zhovnir, National Metallurgical Academy of Ukraine, 4, Haharina ave., 49600, Dnipro, Ukraine, tel. +38 (056) 374-89-36, e-mail kaf.material@metal.nmetau.edu.ua
\end{abstract}

Abstract. Purpose. The aim of the study is to improve the methodology for determining the limit degree of technological deformability of metals during the rolling of wedge-shaped samples, as well as to determine the patterns of the complex melt treatment influence on the AlSi7 alloy deformability limit degree when rolling wedge-shaped samples. Methodology. The object of the study is an AlSi7 alloy, modified with complex 0,1\% $\mathrm{Sr}+0,5 \% \mathrm{Sc}$ in cast and Hydrogen melt treated state. The laws of influence of complex melt treatment on the structure and limit deformability of AK7h alloy are investigated. An improved mode is proposed for determining the ultimate degree of metal deformation during the rolling of wedge-shaped samples. An improved technique was used when rolling at a speed of $0,3 \mathrm{~m} / \mathrm{s}$ at the laboratory mill duo 180 . Steel hardened rolls with a roughness $\mathrm{R} \sim 1 \mathrm{mkm}$ and an ungreased surface were installed. The sizes of the initial samples are $h_{01}=3 \mathrm{~mm}, h_{02}=11 \mathrm{~mm}, b_{0}=10 \mathrm{~mm}, l_{0}=46 \mathrm{~mm}$. The microstructure was studied by standard methods on equipment that passed state verification. Originality. A technique for determining the limiting degree of technological deformation of metals during rolling of wedge-shaped samples has been developed. The developed technique is calculated and does not require marking on the lateral surfaces of samples. Parameters of complex treatment of AlSi7 melt alloy (microalloying with $\mathrm{Sr}-\mathrm{Sc}+$ hydrogen melt treatment) were at first determined. The structure and phase composition of the cast aluminum alloy which ensured its rolling with the degrees of the total logarithmic ("true") deformation up to 1,19 were first determined. Practical value. The improved mode of metal deformability limiting degree definition at rolling process of wedge-shaped samples made possible to increase clarity and simplify the experiment. The modification composition and the hydrogen treatment time parameters optimization allows obtaining rolled products from the AlSi7 cast alloy.

Keywords: technological deformability limiting degree; rolling; wedge-shaped samples; cast AlSi7 alloy; hydrogen melt treatment

\section{ХОЛОДНА ПРОКАТКА ЛИВАРНОГО АЛЮМІНІЄВОГО СПЛАВУ}

ДОЛЖАНСЬКИЙ А. М. ${ }^{1}$, докт. техн. наук, проф.,

КУЦОВА В. 3. ${ }^{2}$, докт. техн. наук, проф.,

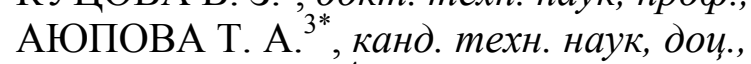

СТОРОЖКО К. Д. ${ }^{4}$, cmyд.,

РИБКІН О. П. ${ }^{5}$, студ.

\footnotetext{
${ }^{1}$ Кафедра якості, стандартизації та сертифікації, Національна металургійна академія України, пр. Гагаріна, 4, 49600, Дніпро, Україна, тел. +38 (056) 746-05-49, e-mail: tk136@ua.fm, ORCID ID:0000-0002-7552-3012

${ }^{2}$ Кафедра матеріалознавства ім. Ю. М. Тарана-Жовніра, Національна металургійна академія України, пр. Гагаріна, 4, 49600, Дніпро, Україна, тел. +38 (056) 374-89-36, e-mail kaf.material@metal.nmetau.edu.ua, ORCID ID: 0000-0003-2413-679X

$3^{*}$ Кафедра матеріалознавства ім. Ю. М. Тарана-Жовніра, Національна металургійна академія України, пр. Гагаріна, 4, 49600, Дніпро, Україна, тел. +38 (056) 374-82-66, e-mail kaf.material@metal.nmetau.edu.ua, ORCID ID 0000-0002-5706-4211
} 


\footnotetext{
${ }^{4}$ Кафедра матеріалознавства ім. Ю. М. Тарана-Жовніра, Національна металургійна академія України, пр. Гагаріна, 4, 49600, Дніпро, Україна, тел. +38 (056) 374-82-66, e-mail: kaf.material@metal.nmetau.edu.ua

${ }^{5}$ Кафедра матеріалознавства ім. Ю. М. Тарана-Жовніра, Національна металургійна академія України, пр. Гагаріна, 4, 49600, Дніпро, Україна, тел. +38 (056) 374-82-66, e-mail: kaf.material@metal.nmetau.edu.ua
}

Анотація. Мета дослідження - удосконалення методики визначення граничного ступеня технологічної деформованості металів під час прокатки клиноподібних зразків, а також з'ясування закономірностей впливу комплексної обробки розплаву на граничний ступінь деформованості сплаву АК7ч за холодної прокатки клиноподібних зразків. Методика. Об'єкт дослідження - ливарний алюмінієвий сплав АК7ч вихідного складу та такий, що містить комплекс $\mathrm{Sr}-\mathrm{Sc}$; в литому стані та після водневої обробки розплаву. Досліджували закономірності впливу комплексної обробки розплаву на структуру та граничну деформованість сплаву АК7ч. Запропоновано удосконалену методику визначення граничного ступеня деформації металів під час прокатки клиноподібних зразків. Ї̈̈ застосовували під час прокатки зі швидкістю 0,3 м/с на лабораторному стані дуо 180 . Були встановлені сталеві загартовані валки із шорсткістю $\mathrm{R} \sim 1$ мкм і незмащеною поверхнею. Розміри вихідних зразків склали $h_{01}=3 \mathrm{mм}, h_{02}=11 \mathrm{mм}, b_{0}=10 \mathrm{mм}, l_{0}=46$ мм. Мікроструктуру вивчали за стандартними методиками на обладнанні, що пройшло держперевірку. Наукова новизна. Отримала розвиток методика визначення граничного ступеня технологічної деформованості металів під час прокатки клиноподібних зразків. Розроблена методика - розрахункова та не потребує нанесення рисок на бічні поверхні дослідних зразків. Уперше визначено параметри комплексної обробки розплаву сплаву АК7ч (мікролегування комплексом $\mathrm{Sr}-\mathrm{Sc}$ + воднева обробка розплаву), а також особливості структури та фазового складу ливарного алюмінієвого сплаву, які забезпечують його прокатку зі ступенем сумарної логарифмічної («істинної») деформації до 1,19 . Практична значимість. Нова методика визначення граничного ступеня деформації металів під час прокатки клиноподібних зразків дозволила підвищити точність і спростити проведення експерименту. Оптимізація складу модифікування і часових параметрів водневої обробки розплаву дозволила отримати прокат із ливарного сплаву АК7ч.

Ключові слова: граничний ступінь технологічної деформації; прокатка, клиноподібні зразки; сплав АК7ч; воднева обробка розплаву

\title{
ХОЛОДНАЯ ПРОКАТКА ЛИТЕЙНОГО АЛЮМИНИЕВОГО СПЛАВА
}

\author{
ДОЛЖАНСКИЙ А. М. ${ }^{1}$, докт. техн. наук, проф., \\ КУЦОВА В. 3. ${ }^{2}$, докт. техн. наук, проф.,

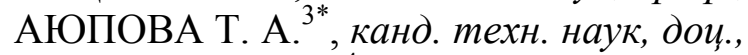 \\ СТОРОЖКО К. Д. ${ }^{4}$, студ., \\ РЫБКИН О. П. ${ }^{5}$, cmyд.
}

\footnotetext{
${ }^{1}$ Кафедра качества, стандартизации и сертификации, Национальная металлургическая академия Украины, пр. Гагарина, 4, 49600, Днипро, Украина, тел. +38 (056) 746-05-49, e-mail : tk136@ua.fm, ORCID ID: 0000-0002-7552-3012

${ }^{2}$ Кафедра материаловедения им. Ю. Н. Тарана-Жовнира, Национальная металлургическая академия Украины, пр. Гагарина, 4, 49600, Днипро, Украина, тел. +38 (056) 374-89-36, e-mail kaf.material@metal.nmetau.edu.ua, ORCID ID: 0000-0003-2413$679 \mathrm{X}$

3* Кафедра материаловедения им. Ю. Н. Тарана-Жовнира, Национальная металлургическая академия Украины, пр. Гагарина, 4, 49600, Днипро, Украина, тел. +38 (056) 374-82-66, e-mail: kaf.material@metal.nmetau.edu.ua, ORCID ID 0000$0002-5706-4211$

${ }^{4}$ Кафедра материаловедения им. Ю. Н. Тарана-Жовнира, Национальная металлургическая академия Украины, пр. Гагарина, 4, 49600, Днипро, Украина, тел. +38 (056) 374-89-36, e-mail: kaf.material@metal.nmetau.edu.ua

${ }^{5}$ Кафедра материаловедения им. Ю. Н. Тарана-Жовнира, Национальная металлургическая академия Украины, пр. Гагарина, 4, 49600, Днипро, Украина, тел. +38 (056) 374-89-36, e-mail kaf.material@metal.nmetau.edu.ua
}

Аннотация. Целью исследования является совершенствование методики определения предельной степени технологической деформируемости металлов при прокатке клиновидных образцов, а также определение закономерностей влияния комплексной обработки расплава на предельную степень деформируемости сплава АК7ч при холодной прокатке клиновидных образцов. Методика. Объектом исследования является литейный алюминиевый сплав АК7ч исходного состава и содержащий комплекс $\mathrm{Sr}-\mathrm{Sc}$; в литом состоянии и после водородной обработки расплава. Исследовали закономерности влияния комплексной обработки расплава на структуру и предельную деформируемость сплава АК7ч. Предложена усовершенствованная методика определения предельной степени деформации металлов при прокатке клиновидных образцов. Ее использовали при прокатке со скоростью 0,3 м/с на лабораторном стане дуо 180. Были установлены стальные закаленные валки с шероховатостью $\mathrm{R} \sim 1$ мкм и несмазанной поверхностью. Размеры исходных образцов составили 
$h_{01}=3 \mathrm{mм}, h_{02}=11$ мм, $b_{0}=10$ мм, $l_{0}=46$ мм. Микроструктуру изучали по стандартным методикам на оборудовании, прошедшем госповерку. Научная новизна. Получила развитие методика определения предельной степени технологической деформируемости металлов при прокатке клиновидных образцов. Разработанная методика является расчетной и не требует нанесения рисок на боковые поверхности опытных образцов. Впервые определены параметры комплексной обработки расплава сплава АК7ч (микролегирование комплексом Sr - Sc + водородная обработка расплава), а также особенности структуры и фазового состава литейного алюминиевого сплава, которые обеспечивают его прокатку со степенью суммарной логарифмической («истинной») деформации до 1,19. Практическая значимость. Новая методика определения предельной степени деформации металлов при прокатке клиновидных образцов позволила повысить точность и упростить проведение эксперимента. Оптимизация состава модифицирования и временных параметров водородной обработки расплава позволила получить прокат из литейного сплава АК7ч.

Ключевые слова: предельная степень технологической деформируемости; прокатка; клиновидные образцы; сплав АК7ч; водородная обработка расплава

\section{Introduction}

One of the methods for studying the technological properties of metals is the evaluation their ultimate degree of deformability to the normal shaping process damage [1]. When rolling, such a damage may be the destruction of the product due to the exhaustion of its plastic properties, slipping of the roll in the rolls, breakage of the rolls due to their insufficient strength, etc. As a rule, identification of the type of process damage is determined by the research purpose and does not present difficulties. Usually, in such experiments, there is a problem of determining the ultimate degree of metal deformation at which a damage occurs. For this, wedge-shaped samples are often used (Fig. 1), fed to the rolls with a thin end, and the value of the limiting logarithmic "true" deformation is determined by the formula [1]:

$$
\varepsilon_{\text {nped }}=\ln \frac{F_{0 x a p}}{F_{1 x a p}},
$$

$F_{0 x a p}$ and $F_{1 x a p}$ - the cross-sectional area of the sample in characteristic sections corresponding to each other, before (index " 0 ") and after (index "1") rolling (for example, at the place of destruction of the sample or its slipping in the rolls).

The value $F_{1 x a p}$ is determined by the measured values of the height $h_{1}$ and width $b_{x a p}$ of the rolled samples in a characteristic section (Fig. 1). It is more difficult to determine a previously unknown place on the initial sample with a height $h_{0 x a p}$ at a distance $x_{0 x a p}$ from its front end, which corresponds to the place of the future characteristic section (fracture) on the rolled sample.

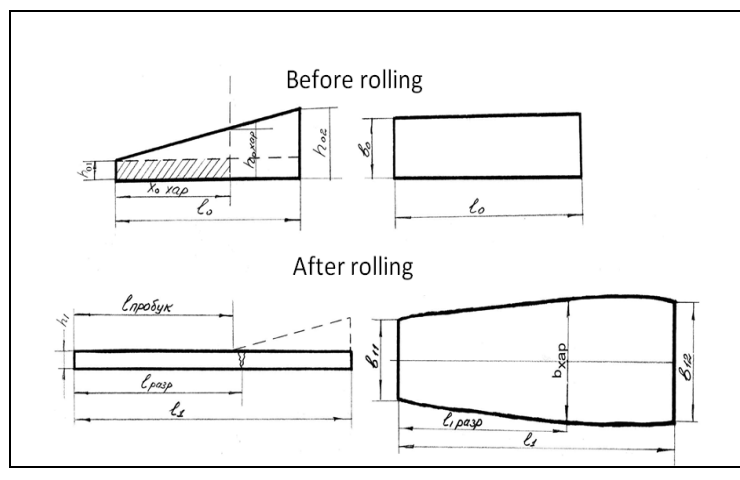

$a$

$b$

Fig.1. Diagram of the wedge-shaped pattern: $a$ - side view; $b$ - top view;

$l_{\text {разр }}, l_{\text {пробук }}$ - distance from the rolled sample front end to the characteristic location of the rolling process failure: destruction or slippage

To solve this problem, a number of longitudinal marks are applied with a certain step on the lateral surface of the initial wedge-shaped sample before rolling [2]. However, the applied ("scratched") strips can be additional stress concentrators, which contribute to premature destruction of the sample during its plastic deformation, and a similar use of labels with coloring pigments is accompanied by a decrease in the accuracy of determining the characteristic cross section due to a change in their size during metal deformation. Also, such sample preparation significantly complicates the experiment.

\section{Purpose}

Improvement of the methodology for determining the limit degree of technological 
deformability of metals during the rolling of wedge-shaped samples, as well as to determine the patterns of the complex melt treatment influence on the AlSi7 alloy deformability limit degree.

\section{Material}

The object of the study is an AlSi7 alloy, modified with complex $0,1 \% \mathrm{Sr}+0,5 \% \mathrm{Sc}$ in cast and Hydrogen melt treated state (Table 1).

Table 1

The Chemical Composition of the AISi7 Alloy

\begin{tabular}{|c|c|c|c|c|c|c|}
\hline \multicolumn{7}{|c|}{ Chemical element, $\%$ mass. } \\
\hline $\mathrm{Al}$ & $\mathrm{Si}$ & $\mathrm{Mg}$ & $\mathrm{Mn}$ & $\mathrm{Fe}$ & $\mathrm{Sr}$ & $\mathrm{Sc}$ \\
\hline & $6.8-7.0$ & $0.2-0.4$ & 0.3 & $0.2-0.4$ & - & - \\
\hline $\begin{array}{l}\mathscr{Z} \\
\tilde{g}\end{array}$ & $6.8-7.0$ & $0.2-0.4$ & 0.3 & $0.2-0.4$ & 0.1 & 0.5 \\
\hline
\end{tabular}

\section{Methodology and results}

During the study, we considered two possible options.

Option 1. The sample is rolled without destruction and slipping. Then the maximum degree of achieved deformation $\varepsilon_{\max }$ is determined by the cross section of its rear end according to the formula (see Fig. 1):

$$
\varepsilon_{\max }=\ln \frac{h_{02} \cdot b_{0}}{h_{1} \cdot b_{12}} .
$$

In this case, the resource of technological deformability of the metal is not exhausted. In fact:

$$
\varepsilon_{\text {nped }}>\ln \frac{h_{02} \cdot b_{0}}{h_{1} \cdot b_{12}} .
$$

Option 2. The sample is rolled with a fixed violation of the process of any kind. For example, the place of destruction of the sample after rolling is determined visually (Fig. 2), and the length $l_{\text {разр }}$ of the sample part to this place (Fig. 1) can be measured.

In this case, it is necessary to determine the degree of deformation of the sample, taking into account its initial height $h_{0 x a p}$ in the cross section, which corresponds to the value $l_{\text {разр }}$. For this case:
- after rolling in a characteristic section (where there is destruction / slipping):

$$
F_{1 x a p}=h_{1} \cdot b_{x a p} ;
$$

- before rolling in the appropriate section (so far unknown):

$$
F_{0 x a p}=h_{0 x a p} \cdot b_{0} .
$$

For wedge-shaped samples in general form:

$$
h_{0 x a p}=h_{01}+\frac{h_{02}-h_{01}}{l_{0}} \cdot x_{0 x a p} \text {. }
$$

From the conditions of volumes constancy:

$$
V_{1}=V_{0} \text {, }
$$

$V_{0}, V_{1}$ - the metal volume before and after the sample rolling to its characteristic section.

If we neglect the curvature of broadening $b_{1}$, which is permissible for $b_{0} \geq h_{02}$ :

$$
V_{1} \approx \frac{1}{2}\left(b_{11}+b_{x a p}\right) \cdot h_{1} \cdot l_{1 x a p} .
$$

This volume corresponds to the original volume:

$V_{0}=h_{01} \cdot b_{0} \cdot x_{0 x a p}+\frac{1}{2} \cdot b_{0} \cdot\left(h_{0 x a p}-h_{01}\right) \cdot x_{0 x a p}$

and taking into account the formula (6):

$V_{0}=h_{01} \cdot b_{0} \cdot x_{0 x a p}+\frac{1}{2} \cdot b_{0} \cdot\left(h_{01}+\frac{h_{02}-h_{01}}{l_{0}} \cdot x_{0 x a p}-h_{01}\right) \cdot x_{0 x a p}$

When substituting expressions (8) and (9) into equality (7) after simple transformations for the root of the quadratic equation that has physical meaning, we have:

$x_{0 x a p}=-\frac{h_{01} \cdot l_{0}}{h_{02}-h_{01}}+\sqrt{\frac{h_{01}^{2} \cdot l_{0}^{2}}{\left(h_{02}-h_{01}\right)^{2}}+\frac{h_{1} \cdot\left(b_{11}+b_{x a p}\right) \cdot l_{0} \cdot l_{1 x a p}}{\left(h_{02}-h_{01}\right) \cdot b_{0}}}$

Then the algorithm for determining the ultimate degree of metal deformation is as follows:

- samples are measured (Fig. 1) and deformed in one pass with the provoked possibility of disruption of the rolling process. After rolling, the position $l_{\text {разp }}$ of the characteristic cross section is visually determined; 
- the required dimensions of the sample are measured after rolling, and the value $x_{0 x a p}$ is calculated by the formula (10);

$-h_{0 x a p}$ determined by expression (6);

$-F_{0 x a p}-$ determined by expression (5);

$-F_{1 x a p}$ - determined by expression (4);

- ultimate degree of deformation $\varepsilon_{\text {nped }}-$ according to the formula (1).

An improved technique was used when rolling at a speed of $0,3 \mathrm{~m} / \mathrm{s}$ at the laboratory mill duo 180. Steel hardened rolls with a roughness $R_{a} \approx 1$ M $\mathrm{kM}$ and an ungreased surface were installed. The sizes of the initial samples according to Figure 1 are $h_{01}=3 \mathrm{~mm}$, $h_{02}=11 \mathrm{~mm}, b_{0}=10 \mathrm{~mm}, l_{0}=46 \mathrm{~mm}$.

In the first series of experiments, samples of cast alloys AlSi7 and AlSi7( $\mathrm{Sr}, \mathrm{Sc})[3 ; 4]$ in the cast state and after hydrogen treatment carried out in accordance with [5] modes were rolled with a gap between the rolls less than $h_{01}$ (Fig. 1). Each experiment is duplicated 3 times.

After rolling, the samples were measured with an accuracy of $0,01 \mathrm{~mm}$ using a micrometer (thickness, width) and $0,1 \mathrm{~mm}$ with a caliper (length).

The appearance of characteristic samples before and after rolling is shown in Figure 2. From these data it is seen that the determination of the size of the samples after rolling does not cause difficulties.

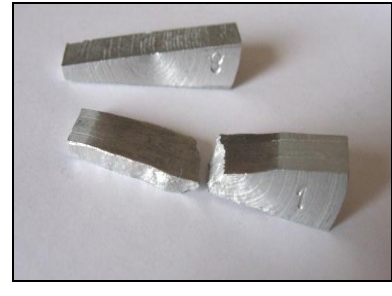

$a$

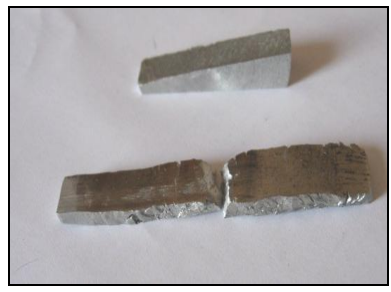

c

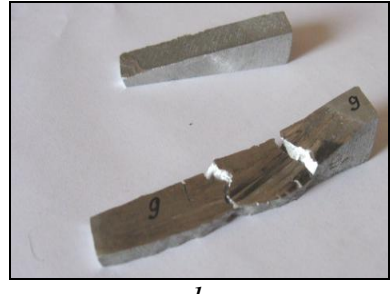

$b$

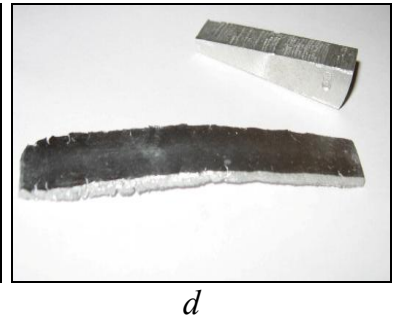

Fig. 2. View of samples of AlSi7 and AlSi7 (Sr, Sc) alloys in initial state and after technological deformability tests: $a, b-A l S i 7 ; c, d-A l S i 7(S r, S c) ; a, c-$ cast state; $b, d-$ after hydrogen melt treatment
The microstructures of AlSi7 and AlSi7(Sr, Sc) alloys in the cast state and after hydrogen treatment are presented in Figures 3 and 4 , and the quantitative dependences of the structure characteristics (D, A - size and the shape parameter of eutectic silicon crystals, respectively, $\mathrm{L}$ is the distance between silicon crystals in eutectic) are in Figure 5.

Data of Figures 4-5 indicate the geometric orientation of $\alpha-\mathrm{Al}$ grains in the direction of the principal axis of deformation and partial crushing of eutectic silicon and intermetallic phases.

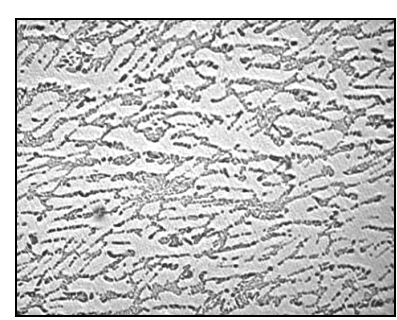

$a$

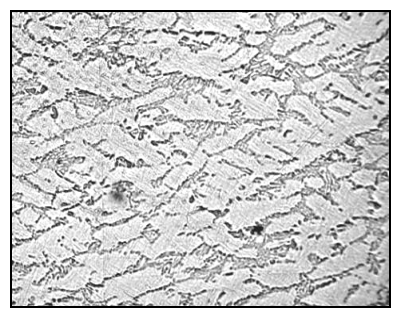

c

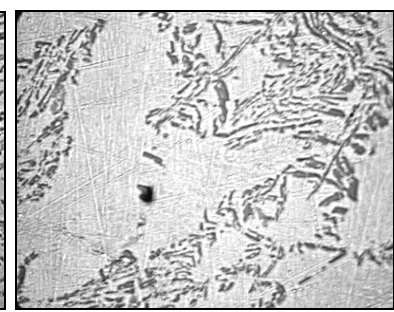

$b$

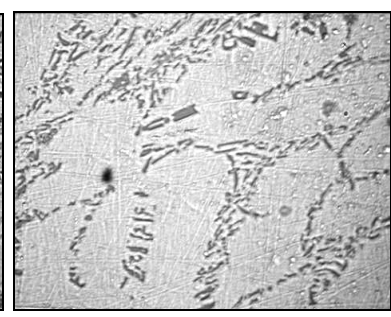

$d$
Fig. 3. Structure of the AlSi7 alloy in the cast state (a, b) and after hydrogen treatment $(c, d)$ : $a, c-\times 100 ; b, d-\times 500$

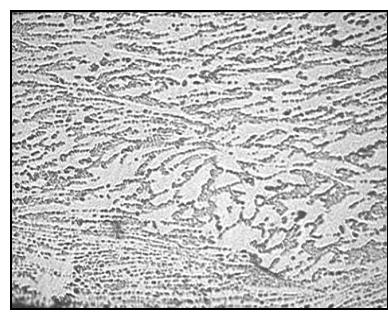

$a$

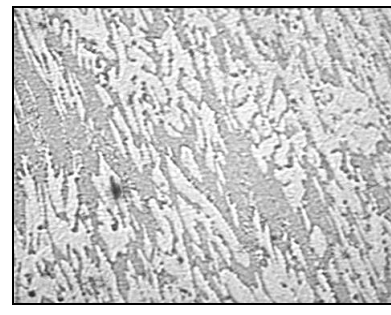

c

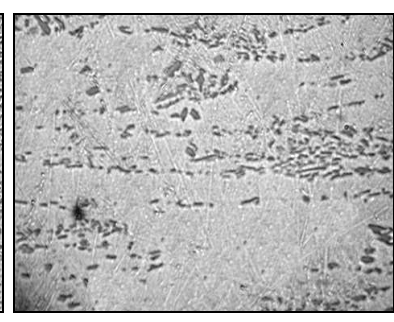

$b$

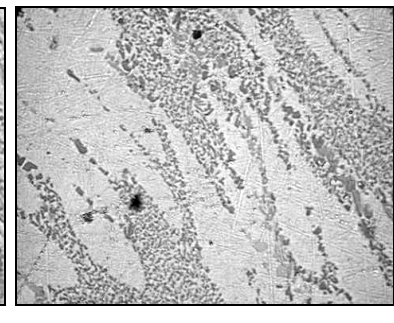

$d$
Fig.4. Structure of AlSi7 (Sr, Sc) alloy in the cast state $(a, b)$ and after hydrogen treatment $(c, d)$ : $a, c-x 100 ; b, d-\times 500$ 
The decrease in the average size of eutectic silicon crystals, the shape parameter of eutectic silicon crystals is associated with the grinding of eutectic silicon, especially in coarse-grained eutectics, and the orientation of the eutectic silicon crystals in the direction of the principal deformation axis.

The results of the deformability limit calculations of the tested samples are presented in Figure 6.

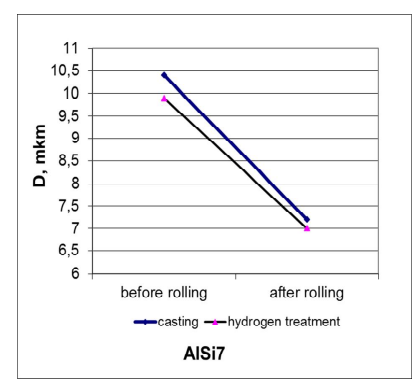

$a$

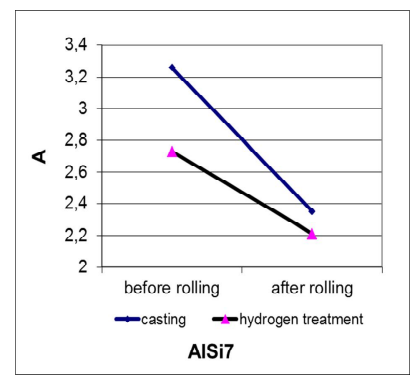

$c$

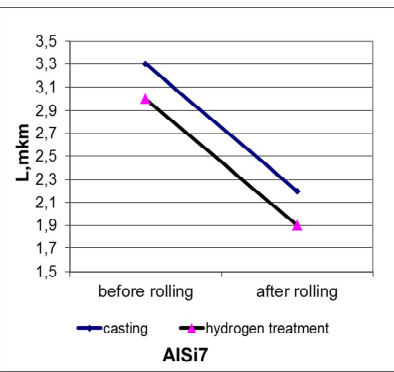

$e$

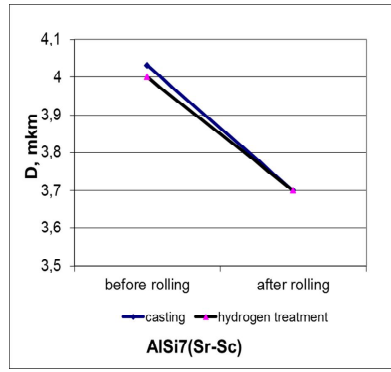

$b$

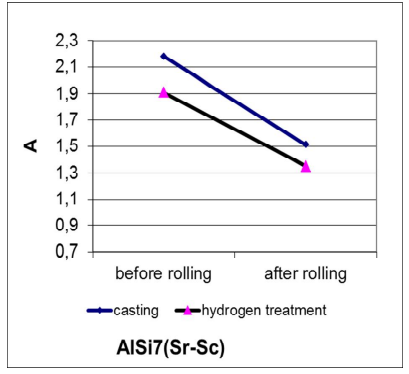

$d$

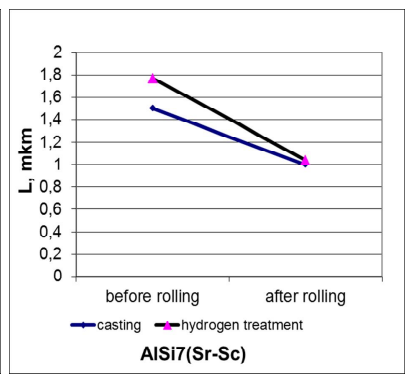

$f$
Fig. 5. The AlSi7 and AlSi7(Sr, Sc) alloys structure characteristics dependences in the cast state and after hydrogen treatment: $a, b$ - the size of the eutectic silicon crystals, $c, d$ - the eutectic silicon crystals shape parameter, $e, f$ - the distance between silicon crystals in eutectic a, $c, e-A l S i 7, b, d, f-A l S i 7(S r, S c)$

It is shown that the greatest influence on the deformability of the AlSi7 alloy is exerted by the complex physicochemical treatment of the melt - microalloying with strontium and scandium at an optimal concentration of [2-3] - hydrogen treatment (20 minutes). The deformability of the alloy increases by $60 \%$ compared to the cast alloy of the original composition.

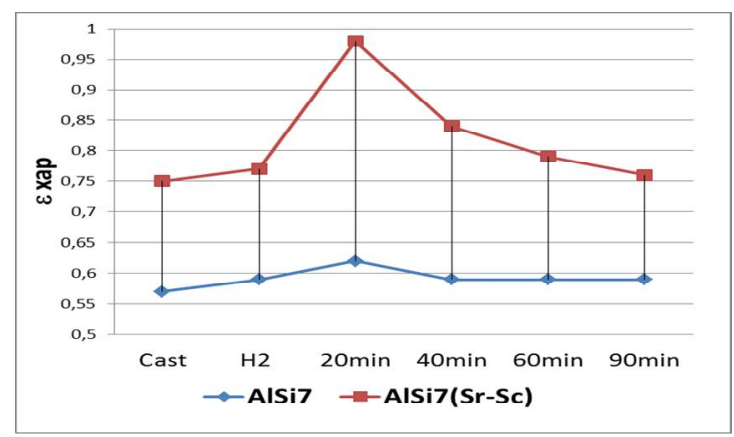

Fig. 6. Dependence of technological deformability of AlSi7 and AlSi7 $(\mathrm{Sr}, \mathrm{Sc})$ alloys - on the mode of hydrogen melt treatment

\section{Conclusions}

1. The improved method for determining the ultimate degree of metal deformation during rolling of wedge-shaped samples is proposed. It allows increasing accuracy and simplifying the experiment.

2. The method is tested in laboratory conditions for the detection of a rational combination of factors of complex influence in the microalloying strontium-scandium complex and hydrogen melt treatment, which provide a significant increase in the cast aluminum alloy deformability.

3. The obtained dependences of technological deformability on the composition of the AlSi7 alloy and the mode of hydrogen treatment of its melt indicate an increase in the deformability of the alloy by $60 \%$ with the complex physicochemical effect of microalloying with strontium $\mathrm{e}$ and scandium and hydrogen melt treatment for 20 minutes compared with cast alloy.

4. The structure of AlSi7 and AlSi7 (Sr, Sc) alloy in the cast state and after hydrogen treatment according to optimal modes after rolling with the ultimate degree of deformation was studied. There is a geometric orientation of the grains of $\alpha-\mathrm{Al}$ solid solution in the direction of the principal axis of deformation and partial crushing of eutectic silicon and intermetallic phases.

5. For the first time, the method of rolling obtained the strip $2,4 \mathrm{~mm}$ thick from the workpiece of alloy AlSi7 (Sr, Sc) with a 
maximum thickness of $11 \mathrm{~mm}$, which allows to expand the use of foundry alloy AK $7 \mathrm{~h}$ for the manufacture of products both by casting and using pressure treatment methods. The true deformation of the AlSi7(Sr,Sc) alloy after hydrogen treatment (20 min) was 1,19 .

\section{REFERENCES}

1. Ilyukovich V.M., Ogurtsov A.P., Nekhaev N.Ye. and Yershov S.V. Teoreticheskie osnovy`obrabotki metallov davleniem: monografiya [Theoretical foundations of metal forming : monograph]. Dnipropetrovsk : RVA :DniproVAL", 2001, vol. 1, 518 p. (in Russian).

2. Grudev A.P. Trenie i smazka pri obrabotke metallov davleniem [Friction and lubrication in metal forming]. Moscow : Metallurgiya, 1982, 312 p. (in Russian).

3. Kutsova V.Z. and Ayupova T.A. Vliyanie mikrolegirovaniya Sr i Sc na strukturu splava AK7ch [The effect of microalloying $\mathrm{Sr}$ and $\mathrm{Sc}$ on the structure of AK7ch alloy]. Stroitel stvo, materialovedenie, mashinostroenie [Civil Engineering, Material Science, Machine Engineering]. Vol. 36, p.1, Dnipropetrovsk : PSACEA. 2006, pp. $201-209$. (in Russian).

4. Kutsova V.Z., Ayupova T.A. and Ambrazhej M.Yu. Vliyanie mikrolegirovaniya Sr i Sc na fazovy $j$ sostav $i$ svojstva AK7ch [The effect of microalloying $\mathrm{Sr}$ and $\mathrm{Sc}$ on the phase composition and properties of AK7ch]. Stroitelstvo, materialovedenie, mashinostroenie Civil Engineering, Material Science, Machine Engineering]. Vol. 41, p. 1, Dnipropetrovsk : PSACEA, 2007, pp. 18-30. (in Russian).

5. Kutsova V.Z. and Ayupova T.A. Vliyanie vodorodnoj obrabotki rasplava na strukturu i svojstva splava tipa AK7ch [The effect of hydrogen treatment on the structure and properties of the alloy type AK7ch]. Metaloznavstvo ta termichna obrobka metaliv [Metal Science and Heat Treatment of Metals]. 2008, no. 4, pp. 50-61. (in Russian).

\section{СПИСОК ВИКОРИСТАНИХ ДЖЕРЕЛ}

1. Илюкович В. М., Огурцов А. П., Нехаев Н. Е., Ершов С. В. Теоретические основы обработки металлов давлением : монография (в 2 т.). Днепропетровск : РВА «Дніпро-ВАЛ», 2001. Т. 1. 518 с.

2. Грудев А. П. Трение и смазка при обработке металлов давлением. Москва : Металлургия, 1982. 312 с.

3. Куцова В. 3., Аюпова Т. А. Влияние микролегирования $\mathrm{Sr}$ и Sc на структуру сплава АК7ч. Строительство, материаловедение, машиностроение. Вып. 36, ч. 1. Днепропетровск : ПГАСА, 2006. C. 201-209.

4. Куцова В. 3., Аюпова Т. А., Амбражей М. Ю. Влияние микролегирования Sr и Sc на фазовый состав и свойства АК7ч. Строительство, материаловедение, машиностроение. Вып. 41, ч. 1. Днепропетровск : ПГАСА, 2007. С. 18-30.

5. Куцова В. 3., Аюпова Т. А. Влияние водородной обработки расплава на структуру и свойства сплава типа АК7ч. Металознавство та термічна обробка металів. 2008. № 4. С. 50-61.

Надійшла до редакції : 12.02.2020 p. 